\title{
Management of Islamic Higher Education Based on Benchmarking and Information Technology in the Revolutionary Era 4.0
}

\author{
Abd Hamid Wahid ${ }^{1}$, Kholilur Rahman ${ }^{2}$, Najiburrahman ${ }^{3}$, Ahmad Fauzi $^{4}$, Hasan Baharun ${ }^{5}$ and \\ Chusnul Muali ${ }^{6}$ \\ Islamic Faculty, Nurul Jadid University, Paiton, Probolinggo, Indonesia ${ }^{1}$ \\ Tarbiya Faculty, IAI Ibrahimy, Genteng, Banyuwangi, Indonesia ${ }^{2}$ \\ Islamic Faculty, Nurul Jadid University, Paiton, Probolinggo, Indonesia ${ }^{3}$ \\ Departement of Islamic Education, IAI Zainul Hasan, Probolinggo, Indonesia ${ }^{4}$ \\ Islamic Faculty, Nurul Jadid University, Paiton, Probolinggo, Indonesia ${ }^{5}$ \\ Islamic Faculty, Nurul Jadid University, Paiton, Probolinggo, Indonesia ${ }^{6}$ \\ $\left\{\right.$ hamidw@gmail.com ${ }^{1}, 1$ lilur66@gmail.com ${ }^{2}$, nageev@gmail.com ${ }^{3}$, \\ fauzi_nov4@yahoo.co.id ${ }^{4}$, ha54nbaharun@gmail.com ${ }^{5}$,yayahdaddy@gmail.com $\left.{ }^{6}\right\}$
}

\begin{abstract}
Nowadays, Islamic higher education must be able to understand the change and do the transformation of management in various sectors. In this perspective, as one of the efforts to improve quality and competitiveness in the era of revolution 4.0. Therefore, Islamic higher education needs to make a breakthrough, by building benchmarking among universities. Besides, it is also necessary to transform the management of information technology, towards a model of Islamic higher education becoming an international class. This study used a qualitative approach in term of case studies. Therefore, this research was natural, descriptive and inductive, by understanding the meaning behind the phenomenon or event in the subject under study. The results of this study explained that the significance of the development of the quality of higher education at Nurul Jadid Paiton Probolinggo University could not be separated from benchmarking as an approach and strategy to achieve the progress. In addition, to effectively implement benchmarking, Nurul Jadid University used SWOT analysis for an internal and external environment of the organization.
\end{abstract}

Keywords: Transformation, Islamic Higher Education, Benchmarking.

\section{Introduction}

Various problems of Islamic higher education; foundational or operational, have not been able to be solved well. This problem became a tangled thread which continued to attract the attention of practitioners and thinkers of Islamic education to be parsed and found its base. Besides, the existence of Islamic higher education is underestimated [1], as a second class education. Even though, it has been studied and equated with other public higher education. Universally, these views are based on two aspects, namely the internal problem of managing the quality of Islamic higher education and external problems that have not been able to respond to the needs of society [2]. Therefore, Malik Fajar stated that the education problem 
above is caused by a system of management, a culture of performance and the quality of human resources [3]. Whereas the presence of Islamic higher education must be able to meet the demands of society or (himmah al-mujtama) on a macro scale, as Mastuhu explained that the role of Islamic education must be able to adjust according to the times which are proactively and anticipatively carried out [4]. Therefore, Islamic education is seen as an investment and at the same time becomes a human and investment capital for a better future $[5]$.

In this context, Islamic education must be able to adapt to the change and metamorphosis of management in all sectors. Thus as an effort to improve the quality and competitiveness referred to, Islamic higher education needs to make a breakthrough, through benchmarking among universities. Besides, it requires the transformation of information technology management. Theoretically, benchmarking is one of cooperation model through the process of accelerating the transformation of the management of Islamic higher education. Hence, the strategy is understood as one of the strategic choices in improving the quality of Islamic higher education; this view is as is done by Nurul Jadid Paiton Probolinggo University. The management of transformation through benchmarking and information technology, aims to strengthen the existence of higher education and improve competitiveness in this revolutionary era 4.0

Based on the results of a field study at Nurul Jadid Paiton Probolinggo University, in the last few years, there have been many changes in various sectors, this is aimed at improving the quality of the intended college graduates. Besides, as one aspect to respond to the dynamics of global development and fulfill the demands of the community. Therefore, the University of Nurul Jadid Paiton Probolinggo continuously carried out many breakthroughs through benchmarking and information technology management as one of its models. In this context, this study aims to describe and explain various aspects of the management of Islamic higher education at Nurul Jadid Paiton Probolinggo University, in making many changes both institutionally and the quality development aspects of graduation, as an Islamic university in the form of Universities in Probolinggo East Java.

\subsection{The paradigm of Benchmarking in Management Transformation}

Practically, the management of Islamic higher education quality is very dependent on educational institutions. Therefore, the transformation of the management in Islamic higher education through a benchmarking approach is one of the strategic models in managing the quality of Islamic higher education today [6]. In this context, the management transformation paradigm is expected to bring a climate of change to Islamic education institutions, through operational steps to realize the ideals of Islamic education; empower institutions by rearranging the system; improve institutional management, and improve the quality of human resources[7]. Therefore, as a leader of educational institutions, it must have a visionary view and approach to the process of achieving his vision and mission, namely through a benchmarking approach as the orientation of the development of Islamic higher education.

Theoretically, the benchmarking paradigm is one model approach that focuses more on transformation in the field of education management through the acceleration process [8], namely by setting several standards in managerial activities, both in the process and the results achieved in a certain period [9]. Therefore, benchmarking is believed to be one approach that is considered strategic and effective enough to develop the quality of Islamic higher education, through a continuous process of improvement, by focusing on changes in academic culture, improving performance and improving the quality of human resources [8]. In this context, the 
benchmarking strategy carried out by a leader must be able to act as an innovator [10], besides having new ideas for innovating institutional development, having the ability to implement these innovative ideas, and organizing a more conducive and teamwork oriented.

\subsection{Benchmarking Model in Management Transformation}

In historical studies, benchmarking was born as an effort to evaluate and improve the quality of an organization, both profit, and socially oriented organizations. Therefore, benchmarking can only be done through competitive benchmarking with the aim of facing competition towards achieving the intended quality of organizations, especially in the world of Islamic education. Achieving the quality of Islamic higher education can only be achieved well, if higher education leaders can transform various sectors of organizational life, including in changing performance management in a more productive direction, through benchmarking as an approach, with the aim measure the productivity and performance achievements of Islamic higher education [11]. This view, as explained by Watson, that benchmarking is an activity carried out continuously to direct and measure performance achievements in an organizational environment [12].

Departing from the study, benchmarking is an activity in an organization - Islamic higher education - to hold evaluations and be carried out continuously, by making comparisons between better internal organizations and other organizations. Under these conditions, the internal organization above can identify, adopt and apply better practices and become part of the standards used, as an effort to make improvements. Thus several models in applying benchmarking, among others; a) self-assessment, is a process to solve the problem at hand and make improvements, b) comparison is identifying other organizations to be used as a comparison material in benchmarking, c) analysis and adaptation are conducting reflection in the internal environment of the organization by evaluating some of its shortcomings, d) planning and implementing, what is needed and done, by building communication within the organization to achieve the improvement process, e) providing feedback and evaluation, namely observing and evaluating what is done and the results achieved.

In this context, several steps in applying to benchmark to an organization, especially in education, can be carried out as follows; 1) establishing educational mission, vision and strategic plan, 2) constructing the change and benchmarking organization team, 3) forming processes related to topics to measure performance, 4) settling standardization as a measure of change, and 5) determining the human resources needed [8].

\section{Method}

This field research design uses qualitative research with a case study approach. Therefore, this study is natural, descriptive and inductive, the existence of researchers trying to find the meaning behind the phenomenon or event in the subject under study. The data collection is done through; deep interview, participation observation, documentation and focus group discussion. Data analysis using Spradley, namely; domain analysis, taxonomy analysis, selection' and componential analysis.

\section{Result and discussion}

Based on the results of the study, benchmarking was one model of the approach to transforming in the field of management of Islamic higher education, as an approach to face 
future competition. Therefore, Islamic higher education must be able to understand the change and transformation of management in various sectors. Thus as an effort to improve the quality and competitiveness referred to, Islamic higher education needs to make a breakthrough, through benchmarking among universities. Besides, it requires the transformation of information technology management. Theoretically benchmarking is one model of cooperation through the process of accelerating the transformation of the management of Islamic higher education. Hence, the strategy is understood as one of the strategic choices in improving the quality of Islamic higher education; this view is as is done by Nurul Jadid Paiton Probolinggo University. The transformation of management through benchmarking and information technology [13], aims to strengthen the existence of higher education and improve competitiveness in this revolutionary era 4.0.

In recent years, the change in Nurul Jadid Paiton Probolinggo University is a breakthrough in pesantren based higher education. The dynamics of this change cannot be separated from benchmarking as a strategy used through the following steps; a) formulating the pesantrenbased university's vision and mission, b) building changes in the organizational environment, c) setting standards for university changes as a measure of change, d) improving the quality of human resources in developing change, e) building collaboration with several universities. In this context, the University of Nurul Jadid Paiton Probolinggo, as a pesantren-based higher education constantly strives to improve its institutional quality, by carrying out the analysis as follows; 1) self-evaluation or self-assessment is a process to solve the problems faced and make the process of improvement, 2) comparison, namely identifying other organizations to be used as a comparison material in benchmarking, 3) analysis and adaptation are conducting reflection in the internal environment of the organization by evaluating some of its shortcomings, 4) planning and implementation, on what is needed through an effective communication process within the organization, 5) conducting feedback and evaluation, namely observing and evaluating the results achieved.

The significance of the institutional change and the development of the quality of higher education at the Nurul Jadid Paiton Probolinggo University cannot be separated from benchmarking as an approach and strategy achieved in that progress. Therefore, benchmarking can be carried out effectively, if using a SWOT analysis in the internal and external environment of Nurul Jadid Paiton Probolinggo University. The analysis study is intended to determine the existence of the organization and the achievement of the intended quality of education.

\section{Conclusion}

Various problems of Islamic higher education, ranging from being foundational or operational, have not been able to be resolved properly. This problem became a tangled thread which continued to attract the attention of practitioners and thinkers of Islamic education to be parsed and found its base. Islamic higher education must be able to understand the change and transformation of management in various sectors. Thus as an effort to improve the quality and competitiveness referred to, Islamic higher education needs to make a breakthrough, through benchmarking among universities. Besides, it requires the transformation of information technology management (communication technology management). This view, as was done by Nurul Jadid Paiton Probolinggo University. The intended management transformation, through benchmarking and information technology, aims to strengthen the existence of higher education and improve competitiveness in this revolutionary era 4.0. Therefore, the University 
of Nurul Jadid Paiton Probolinggo continuously carried out many breakthroughs through benchmarking and information technology management as one of its models.

\section{References}

[1] M. Fadjar, Madrasah dan Tantangan Modernitas. Bandung: Mizan, 1998.

[2] P. Munn, Parents and School; Customers, Managers or Partners. London and New York: Routledge, 1993.

[3] A. Fauzi, "Pengembangan Human Relation Perspektif Nilai-Nilai Al-Qur'an," Mutawatir, vol. 1, no. 2, pp. 168-179, 2015.

[4] Mastuhu, Memberdayakan Sistem Pendidikan Islam. Jakarta: Logos, 1999.

[5] A. Fauzi, "Organizational Culture of Islamic Public Education Management a Discurtive," in Proceeding International Conference on Islamic Education (ICIED), 2017, pp. 130-36.

[6] A. Fauzi, H. Baharun, A. Mundiri, and M. Manshur, Umar, "E-Learning in Pesantren : Learning Transformation based on the Value of Pesantren," J. Phys. Conf. Ser., vol. 1114, pp. 1-6, 2018.

[7] M. Bakri, Pengembangan Sumber Daya Manusia dalam Paradigma Islam. Surabaya: Visipress Media, 2010.

[8] A. Bakhtiar, Penguatan Tata Kelola PTKI Swasta, Inovasi Kelembagaan dan Manajemen. Jakarta: Direktorat Jenderal Pendidikan Islam kementerian Agama RI, 2016.

[9] M. dan T. Supriyatno, Manajemen dan Kepemimpinan Pendidikan Islam. Bandung: Refika Aditama, 2008.

[10] P. M. Mutohar, Manajemen Mutu Sekolah: Strategi Peningkatan Mutu dan Daya Saing Lembaga Pendidikan Islam. Jogjakarta: Ar-Ruzz Media, 2013.

[11] T. Y. Dan, Manajemen Sumber Daya Manusia: Teori, Aplikasi dan Isu Penelitian. Bandung: Alfabeta, 2011.

[12] M. dan B. Saskin, Understanding and Assessing Organizational Leadership. Leadership Library Of America: West Orange,NJ, 1990.

[13] Bogdan, Robert, \& Biklen, S.K., Qualitative Research for Education; an Introduction to Theory and Methods. Boston: Allyn and Bocan Inc, 1992. 